\title{
The Sulfur Pathway and Diagnosis of Sulfate Depletion in Grapevine
}

\author{
Sílvia Tavares and Sara Amâncio
}

\begin{abstract}
Sulfur is an essential nutrient to all plant species. Plants assimilate sulfur in a well-described pathway, which has been taken up by roots. Regulatory mechanism has been the subject of many research papers. However, recent studies highlighted differences between crop plants and the model plant Arabidopsis thaliana. Our work focuses on the identification of genes involved in the sulfur metabolism in the Vitis vinifera genome, and their response to sulfur deficiency and other abiotic stress endured by grapevine in the field, namely water stress. Here, we describe the identification and brief characterization of the first assimilation enzymes involved in the sulfur pathway, the enzyme responsible for sulfur activation, ATP sulfurylase (ATPS), and the two enzymes that reduce sulfate to sulfide, Adenosine $5^{\prime}$-phosphosulate reductase (APR) and Sulfite reductase (SiR). A reduction was observed in the number of ATPS and APR isoforms identified in $V$. vinifera genome when compared to A. thaliana or Glycine max genomes. Two ATPS isoforms were present in the Vitis genome, of which only ATPS1 transcript was detected in the tested tissues, and one APR isoform, suggesting an absence of redundancy in the role of both enzymes. ATPS1, APR and SiR transcript level was up-regulated in response to 2 days exposure to sulfur deficiency in $V$. vinifera cell cultures, which was completely reversed by the addition of GSH to the culture medium. Apparently, oxidative stress triggered GSH has a pivotal role in the regulation of $A T P S 1, A P R$ and $S i R$ transcription level, since their up-regulation was observed in mRNA from field grapevine berries under water stress, which is known to induce oxidative stress.
\end{abstract}

Grapevine (Vitis vinifera L.) is one of the most important crops worldwide for winemaking and also for table grapes. Grapevines can be successfully grown in a range of different climates and management conditions. Global climate changes are associated with water deficit and high evapotranspiration rates that can affect berry development, yield, and wine quality (Hannah et al. 2013).

S. Tavares $•$ S. Amâncio $(\varangle)$

LEAF, Instituto Superior de Agronomia, Universidade de Lisboa, Lisboa 1349-017, Portugal

e-mail: samport@isa.ulisboa.pt 
In plants sulfur $(\mathrm{S})$ is a major essential plant nutrient required for plant growth and development. Unlike animals, vascular plants use sulfate $\left(\mathrm{SO}_{4}{ }^{2-}\right)$ taken by the root system as the primary S source for plant growth (Clarkson et al. 1993) and reduce $\mathrm{SO}_{4}{ }^{2-}$ to sulfide $\left(\mathrm{S}^{2-}\right)$ in plastids of phototrophic organisms, including vascular plants (Shibagaki and Grossman 2008). Sulfide is further assimilated into the amino acids cysteine and methionine. Then most sulfate taken up by plants is incorporated into proteins (Leustek and Saito 1999; Leustek et al. 2000). Organic sulfur can be found in glutathione (GSH), the thiol tripeptide that mediates redox reactions by the interchange of dithiol-disulfide. In addition, several secondary S-metabolites have been suggested to play key roles in defense against pathogens (Hell and Kruse 2007) such as glucosinolates, which are produced mostly by members of the Brassicaceae.

Sulfate assimilation in vascular plants is accomplished in three steps catalyzed by enzymes whose codifying genes were confirmed in Vitis vinifera genome: VvATPS1 and 2 (ATP sulfurylase, EC: 2.7.7.4); VvAPSR (APS reductase, EC: 1.8.99.2); VvSiR (sulfite reductase, EC: 1.8.7.1); VvSERAT1-3 (Serine acetyltransferase, EC 2.2.1.30) and $V v O A S T L 1-13$ (O-acetylserine (thiol) lyase, EC 2.5.1.47) (Amâncio et al. 2009).

The Bordeaux mixture, a high-S-content fungicide, has been used since the nineteenth century for the control of downy and powdery mildew in grapevine (Williams and Cooper 2004). Besides its major effect as a fungicide, it was an important source of S. Since sulfur fungicides have been substituted for organic compounds, the $\mathrm{S}$ supply to vineyards was reduced. Recent studies of $\mathrm{SO}_{4}{ }^{2-}$ uptake, assimilation, and symptoms of sulfur deficiency in Vitis species were reported by our group (Tavares et al. 2008, 2013, 2015; Amâncio et al. 2009). In the first study sulfate uptake was correlated with the expression of sulfate transporter genes in cell systems of two Vitis species (V. vinifera and V. rupestris) (Tavares et al. 2008); the second investigation established a link between sulfur deficiency and phenolic compounds (Tavares et al. 2013) and the third work characterized the serine acetyl-transferase protein family revealing major differences to the best described A. thaliana family (Tavares et al. 2015). Altogether the results previously obtained directed our attention to the first steps of sulfate assimilation, namely sulfate activation and reduction, which were explored in different grapevine experimental systems and environmental conditions.

It is largely known that the experimental set up can influence the results. In a study performed to verify differences of plant sensitivity to chemical treatments the sensitivity varied whether species were treated under greenhouse or field conditions (Fletcher et al. 1990). Under water stress different responses were obtained at physiological and transcriptional levels in grapevine plants cultivated in greenhouse and field (Luisa Carvalho, personal communication). Different systems were used to tackle $\mathrm{S}$ metabolism in grapevine. Cell suspensions were selected as biological material to obtain a homogeneous experimental system. Studies with maize cells had reported a response to $S$ deficiency following the same trend as intact plants, a de-repression of sulfate uptake (Clarkson et al. 1999). Also cell cultures allow $\mathrm{S}$ manipulation in short periods. Cell suspensions of $V$. vinifera var. 
Touriga Nacional and V. rupestris were obtained as described in Tavares et al. 2008. Cell suspensions were sourced from liquid culture callus material and were grown in $250 \mathrm{ml}$ flasks on a rotary shaker at $100 \mathrm{rpm}$, in the dark at $25^{\circ} \mathrm{C}$. After at least two weekly cycles in full sulfate $(+\mathrm{S}, 1.5 \mathrm{mM})$ sub-cultures were prepared for sulfate treatments: $+S$ conditions (control) and sulfate depletion $(-S$, sulfate substituted by chloride). Leaves from $V$. vinifera Touriga Nacional subjected to abiotic stress were obtained as described in Rocheta et al. (2014) and Coito et al. (2012). Rooted cuttings were transferred to 31 pots filled with sterilized soil and placed in the growth chamber. The following growth conditions were adjusted: light intensity $200 \mu \mathrm{mol} \mathrm{m} \mathrm{m}^{-2} \mathrm{~s}^{-1}, 16 \mathrm{~h}$ light and $8 \mathrm{~h}$ darkness, $25^{\circ} \mathrm{C}$ at day $/ 23^{\circ} \mathrm{C}$ at night, and watering with nutrient solution when necessary. The potted plants were subjected to drought and sampled when the pre-dawn leaf water potential was $-0.9 \mathrm{MPa}$. V. vinifera cv. Touriga Nacional berries were collected from plants subjected to two irrigation regimes: rainfed (non-irrigation) and full irrigation (water supplied according to evapotranspiration rates) as described in Lopes et al. (2011). Berries were collected at veraison (50\% colored berries) and full maturation.

The analysis of the Vitis vinifera genome indicates the presence of genes of two ATPS isoforms, one APR isoform with two splicing variants and one SiR isoform. ATPS and APR from plant and algae are encoded by small multigene families. A low number of isoforms is usually found in basal land plants and green algae, the studied species disclosing one or two distinct ATPS isoforms, and a APR unique isoform (Kopriva et al. 2007). In Arabidopsis and soybean genomes, genes encoding four ATPS isoforms and three APR isoforms were identified (Anjum et al. 2015; Hatzfeld et al. 2000; Yi et al. 2010). However, similar to Vitis vinifera, in the Oryza sativa genome only two ATPS isoforms were identified (Kopriva et al. 2007) and Selaginella moellendorffii seems to be the only vascular plant that has a unique ATPS (Kopriva et al. 2009). A single gene encodes SiR in Vitis vinifera in accordance with Arabidopsis (Takahashi et al. 2011) while in tobacco and soybean two isoforms were detected (Yi et al. 2010).

In $V$. vinifera the identified genes are located on distinct chromosomes; only ATPS2 shares the same chromosome with two sulfate transporters genes. Both ATPS genes depict five exons and four introns, however ATPS2 is organized in small exons and very long introns, which increased the genomic size from 5.3 to $11 \mathrm{Kbp}$. SiR is organized in eight exons and seven introns. In contrast the APR gene has only four or five exons. Two variants were identified for the APR gene that differ in a small sequence, variant one interpreted the sequence as an intron, in comparison variant 2 incorporated the sequence in the mRNA (Table 1).

The Vitis vinifera sulfate activation and reduction protein sequences present similar traits to other known plant proteins such as protein length and conserved domains (Table 1). V. vinifera ATPS coding regions have the N-terminal leader sequences characteristic for plastid-targeting transit peptides and a conserved ATPS catalytic domain (CD00517, Marchler-Bauer et al. 2011), typical of all described plant ATPS. All four ATPS from Arabidopsis thaliana (Rotte and Leustek 2000) and Glycine $\max (\mathrm{Yi}$ et al. 2010) have been predicted as chloroplast isoforms 
Table 1 Identification of ATP sulfurylase (ATPS), APS reductase (APR) and sulfide reductase $(\mathrm{SiR})$ genes in Vitis vinifera genome

\begin{tabular}{|c|c|c|c|c|c|}
\hline Gene & Chr & Genomic Region $^{\mathrm{a}}$ & mRNA $^{a}$ & Protein $^{a}$ & $\begin{array}{l}\text { Locali- } \\
\text { zation }\end{array}$ \\
\hline ATPSI & 5 & $\begin{array}{l}\text { NW_003724020.1 } \\
5.3 \text { Kbp }\end{array}$ & $\begin{array}{l}\text { XM_002283536.3 } \\
1960 \text { bp }\end{array}$ & $\begin{array}{l}\text { XP_002283572.1 } \\
467 \text { aa }\end{array}$ & C \\
\hline ATPS2 & 18 & $\begin{array}{l}\text { NW_003724132.1 } \\
\text { 11Kbp }\end{array}$ & $\begin{array}{l}\text { XM_002276957.2 } \\
2253 \text { bp }\end{array}$ & $\begin{array}{l}\text { XP_002276993.1 } \\
483 \text { aа }\end{array}$ & $\mathrm{C}$ \\
\hline$A P S r$ & 12 & $\begin{array}{l}\text { NW_003724079. } \\
3.9 \text { Kbp }\end{array}$ & $\begin{array}{l}\text { XM_002269703.3 } \\
\text { (2) } 1928 \text { bp } \\
\text { XM_010658907.1 (1) } \\
1885 \text { bp }\end{array}$ & $\begin{array}{l}\text { XP_002269739.2 } \\
\text { (2) } 467 \text { aa } \\
\text { XP_010657209.1 (1) } \\
498 \text { aа }\end{array}$ & $\mathrm{C}$ \\
\hline SiR & 6 & $\begin{array}{l}\text { NW_003724030.1 } \\
6.4 \text { Kbp }\end{array}$ & $\begin{array}{l}\text { XM_002285362.2 } \\
2690 \text { bp }\end{array}$ & $\begin{array}{l}\text { XP_002285398.1 } \\
687 \text { aa }\end{array}$ & $\mathrm{C}$ \\
\hline
\end{tabular}

Chr chromosome number, ${ }^{\mathrm{a}} \mathrm{NCBI}$ reference numbers, $C$ putative chloroplastic localization predicted in TargetP site (http://www.cbs.dtu.dk/services/TargetP/)

although ATPS activity is detected in chloroplasts and cytosol in Arabidopsis (Rotte and Leustek 2000) and spinach leaves (Lunn et al. 1990). Recently, Bohrer et al. (2015) showed that in Arabidopsis leaves, ATPS2 has a dual localization, namely in cytosol and chloroplasts, suggesting that a downstream methionine in the transit peptide sequence could act as an additional initiation translation site. In addition, such methionine is not present on the transit peptide sequence of ATPS1, 3 and 4. ATPS2 seems to be a distinct ATPS isoform, which probably confers different physiological roles; this isoform is also the only ATPS from Arabidopsis that is not a target to miRNA395 post-transcriptional control (Kawashima et al. 2009). Likewise, only the ATPS2 sequence from Vitis vinifera has an additional methionine on the transit peptide sequence and, contrary to VvATPS1, it is not a target of Vitis miRNA395 as predicted by the psRNATARGET tool (http:// plantgrn.noble.org/psRNATarget/) (Dai and Zhao 2011). In fact, the unrooted tree constructed with Vitis, Arabidopsis, soybean and Populus ATPS protein sequences (Fig. 1a) also shows a group including the ATPS2 sequences and a second group where the other sequences are not clearly separated. If a certain degree of redundancy in ATPS isoforms is observed among other plant species (Kopriva et al. 2009), apparently in the Vitis vinifera genome such redundancy is reduced or absent. A unique APR isoform was identified in the Vitis genome, with two variants that share 94\% sequence homology. Sulfate reduction occurs exclusively in chloroplasts and, similarly to all plant species Vitis APR has a N-terminal transit peptide for plastid-targeting and a conserved multidomain consisting of an reductase domain and a C-terminal thioredoxin-like domain (CD02993, Marchler-Bauer et al. 2011).

Arabidopsis (Kopriva et al. 2009) and soybean (Yi et al. 2010) have three APR isoforms, apparently some level of redundancy exists, since Arabidopsis plants without functional APR1 or APR2 do not show obvious differences when compared with the wild type, however the disruption of APR2 leads to an $80 \%$ decrease in APR activity and an accumulation of sulfate indicating that APR2 is a major 

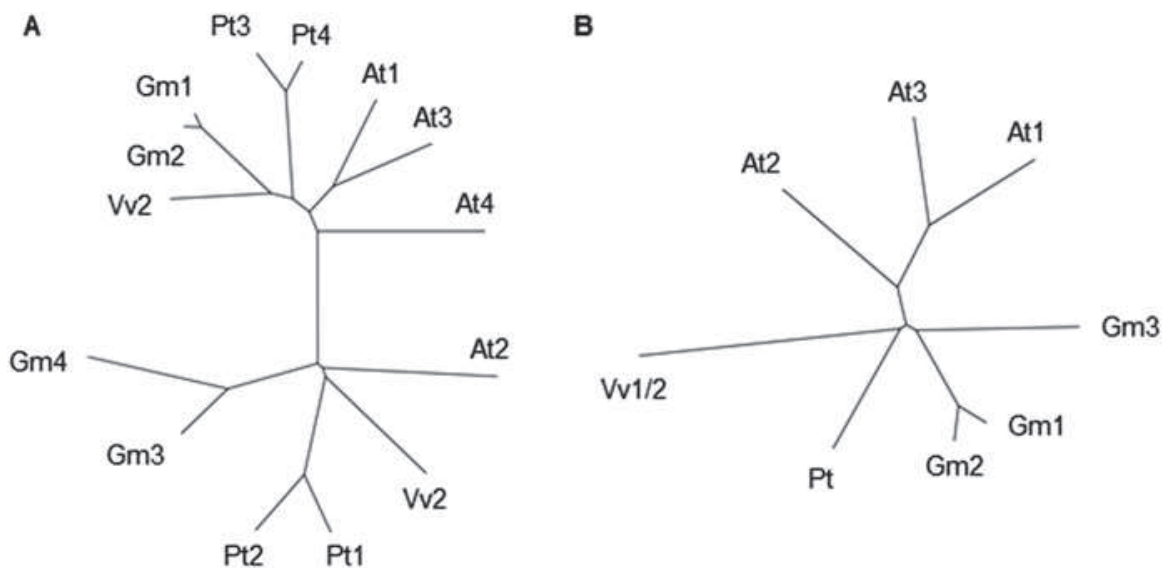

Fig. 1 Phylogenetic analysis of ATPS sulfurylase (ATPS, a) and APS reductase (APR; b) protein sequences. Unrooted tree constructed using the T-Cofee and PHYLIP programs, PRODIST and NEIGHBOR (http://tcoffee.crg.cat/ and http://mobyle.pasteur.fr/cgi-bin/portal.py\#welcome, respectively). At Arabidopsis thaliana, Gm Glycine max, Pt Populus trichocarpa, Vv Vitis vinifera

isoform in Arabidopsis (Loudet et al. 2007). The identification of APR in the Vitis genome shows a lack of redundancy and the phylogenetic analysis of the unique Vitis APR together with APR protein sequences from Arabidopsis, soybean and Populus shows that the Vitis protein is closer to Arabidopsis and soybean APR2. The APR protein sequences from the selected species seem to group better inside each species, which could be determined by species-specific evolution of APR (Fig. 1b). Together with APR, SiR is strictly plastidic. Vitis SiR contains the siroheme and a $[4 \mathrm{Fe}-4 \mathrm{~S}]$ cluster typical of plant SiR proteins and the transit peptide for chloroplast targeting (Table 1).

The presence of transcripts encoding enzymes involved in sulfate activation and reduction, ATPS1 and 2, APR and SiR, were examined in different grapevine tissues by RT-PCR (Fig. 2). ATPS2 was the only gene not detected in RNA isolated from the sampled tissues, namely leaves (young and mature) and roots of potted plants, berries collected in the field and cells from cell culture (Fig. 2b, in berries). $V$. vinifera ATPS2 protein sequence was most similar to the protein sequences of Populus, ATPS1 and ATPS2, and AtAPS2 (Fig. 1a) recently proven to have dual subcellular chloroplastic/cytosolic localization, although a physiological role of the cytosolic isoform remains unknown (Bohrer et al. 2015). It has been speculated that cytosolic ATPS may be linked to cytosolic APS kinase in providing PAPS for the secondary metabolism (Rotte and Leustek 2000), namely in the production of glucosinolates. V. vinifera invests a great deal of resources in secondary metabolites, such as phenolic compounds, and its genome is enriched in genes devoted to secondary metabolism (Velasco et al. 2007). V. vinifera synthesizes no glucosinolates, which might be the reason why ATPS 2 transcripts were not detected in different plant tissues. RNA isolated from berries at veraison showed a very 
A

\begin{tabular}{lllll}
\hline \multicolumn{1}{c}{ Gene } & Roots & Leaves & Berry \\
\hline ATP Sulfurylase & & & \\
VvATPS1 & & & \\
Adenosine Phosphosulfate Reductase & & \\
APR & & & \\
Sulfite Reductase & & & \\
SiR & & & \\
Actin & & & \\
\hline Act & & & \\
\hline
\end{tabular}

B

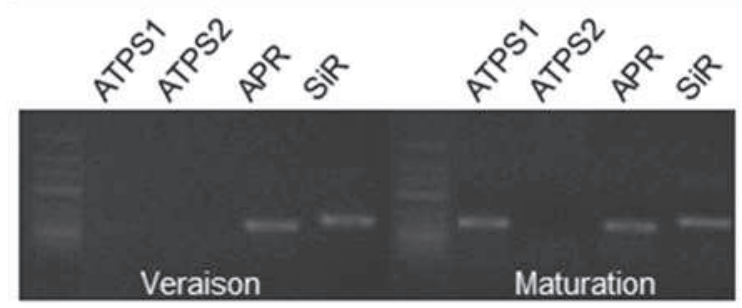

Fig. 2 (a) mRNA detection by RT-PCR in different Vitis vinifera tissues with specific primers design to ATP sulfurylase1 (ATPS1), APS reductase (APR) and sulfide reductase (SiR) sequences identified in Table 1. (b) detection of ATPS1 and 2, APR and SiR transcripts in grapevine berries collected at veraison and full maturation. RNA extraction and RT-PCR were performed according with standard molecular biology techniques

weak signal in RT-PCR using ATPS1 primers, contrary to mature berries RNA which produced a strong signal indicating presence of the gene (Fig. 2b). Interestingly, a group three sulfate transporter was up-regulated at berry maturation (Guillaumie et al. 2011) and in seeds, transcripts for sulfur metabolism genes, namely group three sulfate transporters, were over-represented when compared with pulp transcripts (Grimplet et al. 2007). Together these results suggest a stimulus of sulfur metabolism at berry maturation, in particularly in seeds.

The transcript levels of $V v A T P S 1, V v A P R$ and $V v S i R$ analyzed by qPCR responded equally to $S$ depletion in cell cultures; all genes were up-regulated in cells after 2 days in an $\mathrm{S}$ deficient medium (Fig. $3 \mathrm{a}, \mathrm{b}$ and c), and an increase in mRNA level was observed in $V v A P R$ (Fig. 3b). S deficiency is known to be responsible for increasing the transcript levels of group one sulfate transporters and APR in plant species, including Vitis vinifera (Tavares et al. 2008), the reason why APR activity and sulfate transport are considered to exert the highest control over the S metabolic pathway (Vauclare et al. 2002). Nevertheless ATPS up-regulation was also observed in several plant species, namely Arabidopsis thaliana and Zea mays (reviewed by Anjum et al. 2015). The addition of sulfate and GSH to the $\mathrm{S}$ deficient medium completely reverses the up-regulation of $V v A T P S 1, V v A P R$ and $V v S i R$ transcripts. Interestingly, in Vitis cells the level of GSH as measured by HPLC (Tavares et al. 2015) was the first S compound to 

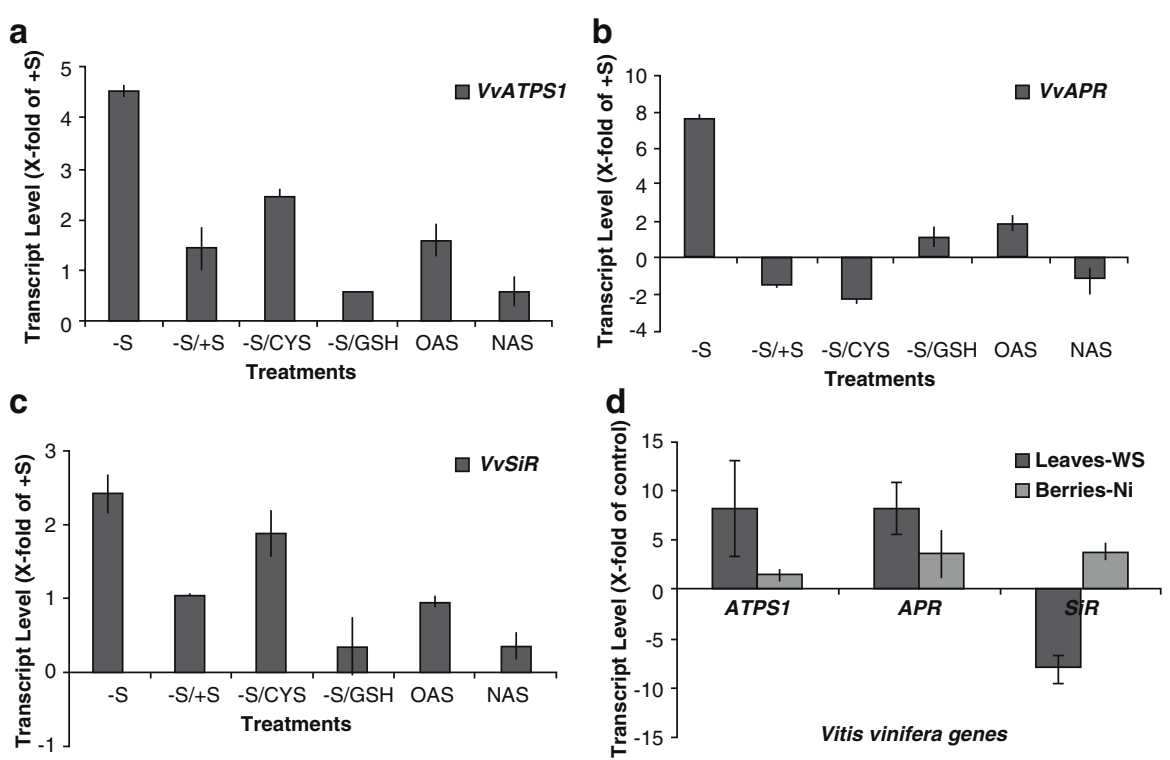

Fig. 3 Relative expression of ATP sulfurylase1 (ATPS1), APS reductase (APR) and Sulfide reductase $(\mathrm{SiR})$ transcripts in grapevine cell culture $(\mathbf{a}, \mathbf{b}$ and $\mathbf{c})$ and leaves and berries $(\mathbf{d})$. (a, b and $\mathbf{c})$. Cells collected after 2 days in sulfur deficiency $(-S)$ and sulfur sufficient $(+S)$ medium, after which sulfur (S), cysteine (cys) and GSH were added to the $-\mathrm{S}$ medium and $O$-acetylserine (OAS) and $N$-acetylserine (NAS) to $+\mathrm{S}$. Relative expression was compared to $+\mathrm{S}$ cells using RT-qPCR. (d) Water stress grapevine leaves and non-irrigated berries relative transcript level of $A T P S 1, A P R$ and SiR was compared to control leaves and full irrigated berries by RT-qPCR

significantly decrease in cells after 1 day in $\mathrm{S}$ deficient medium. Cysteine added to cells in an $\mathrm{S}$ deficient medium also triggered a reversion of the up-regulation observed in the transcript level of $V v A P R$ (Fig. 3b); apparently cysteine had a direct effect on the $V v A P R$ transcription though we only detected a decrease in the amount of cysteine inside the cells 5 days after S limitation (Tavares et al. 2015). OAS is considered to act as a positive regulator of sulfate transporters, and commonly has similar effects under conditions of S deficiency (Takahashi et al. 2011). Consequently OAS added to Vitis vinifera cell culture showed the same up-regulation effect as $\mathrm{S}$ deficiency, although the magnitude was not so drastic (Fig. 3a, b and c).

In leaves from potted plants and berries collected from field plants, both grown under conditions of water stress the VvATPS and VvAPR transcript level increased. In contrast, $V v S i R$ was down-regulated in leaves and up-regulated in berries (Fig. 3d). A change in ATPS activity in response to oxidative stress was reported by Kopriva et al. (2007). Similar results were obtained under conditions of abiotic stress (reviewed in Anjum et al. 2015). A high demand for GSH, an important $\mathrm{S}$-compound in the response to oxidative stress, occurs under water stress. This may unfold an up-regulation effect in the mRNA of the first enzymes of sulfur assimilation. Likewise, the serine acetyltransferase (SAT) mRNA level was up-regulated under water stress conditions in Vitis vinifera leaves (Tavares et al. 2015). 
As $V v S E R A T 2 ; 1$ was up-regulated in leaves of plants under water stress, this result prompted us to test the genes for the first enzymes of the $S$ assimilation pathway (ATPS, APR and SiR) in leaves and berries of plants under water deficit. Although the patterns of transcripts expression were distinctly different between the two plant organs, the results suggest that some enzymes involved in sulfate metabolism are regulated by S-status and by environmental conditions, e.g. water deficit. Our study showed that major characteristics of ATPS, APR and SiR are very well conserved among plant species. However, it would be interesting to highlight differences between these enzymes in order to obtain a complete overview of $S$ assimilation in different plant species.

\section{References}

Amâncio S, Tavares S, Fernandes JC, Sousa C (2009) Grapevine \& sulfur: old partners, new achievements. In: Roubelakis-Angelakis KA (ed) Grapevine molecular physiology \& biotechnology. Springer, Dordrecht, pp 31-52

Anjum NA, Gill R, Kaushik M, Hasanuzzaman M, Pereira E, Ahmad I, Gill SS (2015) ATP-sulfurylase, sulfur-compounds, and plant stress tolerance. Front Plant Sci 6:210

Bohrer AS, Yoshimoto N, Sekiguchi A, Rykulski N, Saito K, Takahashi H (2015) Alternative translational initiation of ATP sulfurylase underlying dual localization of sulfate assimilation pathways in plastids and cytosol in Arabidopsis thaliana. Front Plant Sci 5:750

Clarkson DT, Hawkesford MJ, Davidian J-C (1993) Membrane and long-distance transport of sulfate. In: De Kok LJ, Stulen I, Rennenberg H, Brunold C, Rausen WE (eds) Sulfur nutrition and sulfur assimilation in higher plants: fundamental environmental and agricultural aspects. SPB Academic Publishing, The Hague, pp 3-19

Clarkson DT, Diogo E, Amâncio S (1999) Uptake and assimilation of sulphate by sulphur deficient Zea mays cells: the role of O-acetyl-L-serine in the interaction between nitrogen and sulphur assimilatory pathways. Plant Physiol Biochem 37:283-290

Coito JL, Rocheta M, Carvalho L, Amâncio S (2012) Microarray-based uncovering reference genes for quantitative real time PCR in grapevine under abiotic stress. BMC Res Notes 5:220

Dai X, Zhao PX (2011) psRNATarget: a plant small RNA target analysis server. Nucleic Acids Res 39:W155-W159

Fletcher JS, Johnson FL, McFarlane JC (1990) Influence of greenhouse versus field testing and taxonomic differences on plant sensitivity to chemical treatment. Environ Toxicol Chem 9:169-776

Grimplet J, Deluc LG, Tillett RL, Wheatley MD, Schlauch KA, Cramer GR, Cushman JC (2007) Tissue-specific mRNA expression profiling in grape berry tissues. BMC Genomics 8:1

Guillaumie S, Fouquet R, Kappel C, Camps C, Terrier N, Moncomble D, Delrot S (2011) Transcriptional analysis of late ripening stages of grapevine berry. BMC Plant Biol 11:165

Hannah L, Roehrdanz PR, Ikegami M, Shepard AV, Shaw MR et al (2013) Climate change, wine, and conservation. Proc Natl Acad Sci U S A 110:6907-6912

Hatzfeld Y, Lee S, Lee M, Leustek T, Saito K (2000) Functional characterization of a gene encoding a fourth ATP sulfurylase isoform from Arabidopsis thaliana. Gene 248:51-58

Hell R, Kruse C (2007) Sulfur in biotic interactions of plants. In: Hawkesford MJ, De Kok LJ (eds) Sulfur in plants an ecological perspective. Springer, Dordrecht, pp 197-224

Kawashima CG, Yoshimoto N, Maruyama-Nakashita A, Tsuchiya YN, Saito K, Takahashi H, Dalmay T (2009) Sulphur starvation induces the expression of microRNA-395 and one of its target genes but in different cell types. Plant J 57:313-321 
Kopriva S, Wiedemann G, Reski R (2007) Sulfate assimilation in basal land plants-what does genomic sequencing tell us? Plant Biol 9:556-564

Kopriva S, Mugford SG, Matthewman C, Koprivova A (2009) Plant sulfate assimilation genes: redundancy versus specialization. Plant Cell Rep 28:1769-1780

Leustek T, Saito K (1999) Sulfate transport and assimilation in plants. Plant Physiol 120:637-644

Leustek T, Martin MN, Bick JA, Davies JP (2000) Pathways and regulation of sulfur metabolism revealed through molecular and genetic studies. Annu Rev Plant Physiol Plant Mol Biol 51:141-165

Lopes CM, Santos TP, Monteiro A, Rodrigues ML, Costa JM, Chaves MM (2011) Combining cover cropping with deficit irrigation in a Mediterranean low vigor vineyard. Sci Hortic 129:603-612

Loudet O, Saliba-Colombani V, Camilleri C, Calenge F, Gaudon V, Koprivova A, Daniel-Vedele F (2007) Natural variation for sulfate content in Arabidopsis thaliana is highly controlled by APR2. Nat Genet 39:896-900

Lunn JE, Droux M, Martin J, Douce R (1990) Localization of ATP sulfurylase and $O$-acetylserine (thiol) lyase in spinach leaves. Plant Physiol 94:1345-1352

Marchler-Bauer A, Lu S, Anderson JB, Chitsaz F, Derbyshire MK, DeWeese-Scott C, Gwadz M (2011) CDD: a conserved domain database for the functional annotation of proteins. Nucleic Acids Res 39:D225-D229

Rocheta M, Becker JD, Coito JL, Carvalho L, Amâncio S (2014) Heat and water stress induce unique transcriptional signatures of heat-shock proteins and transcription factors in grapevine. Funct Integr Genomics 14:135-148

Rotte C, Leustek T (2000) Differential subcellular localization and expression of ATP sulfurylase and 5-adenylylsulfate reductase during ontogenesis of Arabidopsis leaves indicates that cytosolic and plastid forms of ATP sulfurylase may have specialized functions. Plant Physiol 124:715-724

Shibagaki N, Grossman A (2008) The state of sulfur metabolism in algae: from ecology to genomics. In: Hell R, Dahl C, Knaff D, Leustek T (eds) Advances in photosynthesis and respiration: sulfur metabolism in phototrophic organisms. Springer, Dordrecht, pp 231-267

Takahashi H, Kopriva S, Giordano M, Saito K, Hell R (2011) Sulfur assimilation in photosynthetic organisms: molecular functions and regulations of transporters and assimilatory enzymes. Annu Rev Plant Biol 62:157-184

Tavares S, Sousa C, Carvalho LC, Amâncio S (2008) De-repressed transporters are strongly repressed after sulfate addition to sulfur depleted Vitis cells. Int J Plant Sci 169:987-997

Tavares S, Vesentini D, Fernandes JC, Ferreira RB, Laureano O, Ricardo-Da-Silva JM, Amâncio S (2013) Vitis vinifera secondary metabolism as affected by sulfate depletion: diagnosis through phenylpropanoid pathway genes and metabolites. Plant Physiol Biochem 66:118-126

Tavares S, Wirtz M, Beier MP, Bogs J, Hell R, Amâncio S (2015) Characterization of the serine acetyltransferase gene family of Vitis vinifera uncovers differences in regulation of OAS synthesis in woody plants. Front Plant Sci 6:74

Vauclare P, Kopriva S, Fell D, Suter M, Sticher L, Von Ballmoos P, Brunold C (2002) Flux control of sulphate assimilation in Arabidopsis thaliana: adenosine $5^{\prime}$-phosphosulphate reductase is more susceptible than ATP sulphurylase to negative control by thiols. Plant J 31:729-740

Velasco R, Zharkikh A, Troggio M, Cartwright DA, Cestaro A et al (2007) A high quality draft consensus sequence of the genome of a heterozygous grapevine variety. PLoS One 2(12), e1326

Williams JS, Cooper RM (2004) The oldest fungicide and newest phytoalexin - a reappraisal of the fungitoxicity of elemental sulphur. Plant Pathol 53:263-279

Yi H, Ravilious GE, Galant A, Krishnan HB, Jez JM (2010) From sulfur to homoglutathione: thiol metabolism in soybean. Amino Acids 39:963-978 


\title{
Impact of Sulfate Deprivation and $\mathrm{H}_{2} \mathrm{~S}$ Exposure on the Metabolites of the Activated Methyl Cycle in Chinese Cabbage
}

\author{
Mei-Hwei Tseng, Chao-Kai Yang, C. Elisabeth E. Stuiver, \\ Chiu-Ching Chang, and Luit J. De Kok
}

\begin{abstract}
The activated methyl cycle is a central metabolic pathway used to generate (and recycle) several important sulfur-containing metabolites including methionine, S-adenosylmethionine (SAM) and S-adenosylhomocysteine (SAH) and enable methylation. We have developed a precise and sensitive method for the simultaneous measurement of several sulfur metabolites based on liquid chromatography coupled with tandem mass spectrometry (LC-MS/MS) and ${ }^{34}$ S-metabolic labeling of sulfurcontaining metabolites including glutathione and the metabolites of the activated methyl cycle. Sulfate deprivation resulted in a decreased biomass production and content of glutathione, methionine, SAH of both shoot and root, and SAM of the root of Chinese cabbage. Foliarly absorbed $\mathrm{H}_{2} \mathrm{~S}$ may able to replace sulfate taken up by the root as sulfur source for growth and an atmospheric concentration of $0.2 \mu 1^{-1}$ alleviated the decrease in the content of sulfur metabolites. The SAM content of the shoot was hardly affected upon sulfate-deprivation, resulting an increase in the SAM/ SAH ratio, indicating a potential higher methylation capacity under this condition.
\end{abstract}

Seedlings of Brassicacea are characterized by their high growth rate (up to $0.4 \mathrm{~g} \mathrm{~g}^{-1}$ $\mathrm{day}^{-1}$ ) and high sulfur demand; the sulfate uptake rate of some species may exceed $40 \mu \mathrm{mol} \mathrm{g}{ }^{-1}$ fresh weight root day ${ }^{-1}$ (Shahbaz et al. 2010; Stuiver et al. 2014; Aghajanzadeh et al. 2016). The uptake of sulfate by the root is adjusted to the sulfur demand for growth, even at an external sulfate concentrations close to the $K_{m}$ value

M.-H. Tseng $(\square)$

Department of Applied Physics and Chemistry, University of Taipei, Taipei 10048, Taiwan e-mail: biomei@utaipei.edu.tw

C.-K. Yang

Department of Forensic Science, Central Police University, Taoyuan 33304, Taiwan

C. E.E. Stuiver • L.J. De Kok

Laboratory of Plant Physiology, Groningen Institute for Evolutionary Life Sciences, University of Groningen, P.O. Box 11103, 9700 CC Groningen, The Netherlands

Chiu-Ching Chang

Department of Applied Chemistry, National Chiao Tung University, Hsinchu 30050, Taiwan 
of the high affinity sulfate transporters (approx. $5 \mu \mathrm{M}$; Koralewska et al. 2007, 2012). The interaction between atmospheric $\mathrm{H}_{2} \mathrm{~S}$ and pedospheric sulfate nutrition of plants has been extensively studied during the last three decades (De Kok 1990; De Kok et al. 2000, 2002, 2007). Foliarly absorbed $\mathrm{H}_{2} \mathrm{~S}$ was directly metabolized into cysteine and subsequently into other organic sulfur compounds, and exposure resulted in an increase in the content of water-soluble non-protein thiol content (viz. cysteine and glutathione) of the shoot (De Kok 1990; De Kok et al. 2000, 2002, 2007). $\mathrm{H}_{2} \mathrm{~S}$ exposure hardly affected the total sulfur and sulfate contents of Brassica, even not at relatively high atmospheric concentrations (De Kok et al. 2000), but resulted in a down-regulation of the uptake of sulfate by the root and reduction in the shoot (De Kok et al. 2000, 2002, 2007; Koralewska et al. 2008; Shahbaz et al. 2014; Aghajanzadeh et al. 2014, 2016). Upon sulfate-deprivation, the assimilated foliarly absorbed $\mathrm{H}_{2} \mathrm{~S}$ may replace sulfate as a sulfur source for growth of Brassica (De Kok et al. 2000, 2002, 2007; Buchner et al. 2004; Koralewska et al. 2008; Shahbaz et al. 2014; Aghajanzadeh et al. 2016). $\mathrm{H}_{2} \mathrm{~S}$ exposure hardly affected the up-regulated expression and activity of the high affinity sulfate transporters in sulfate-deprived Brassica (Koralewska et al. 2008; Shahbaz et al. 2014), and the decrease in shoot to root biomass partitioning upon sulfate deprivation remained largely unaffected upon $\mathrm{H}_{2} \mathrm{~S}$ exposure (Koralewska et al. 2008; Shahbaz et al. 2014; Aghajanzadeh et al. 2016). There is apparently a rather poor shoot to root signaling in Brassica of the regulation of both the sulfate transporters in the root and shoot to root biomass partitioning, indicating that both are determined by the sulfate concentration in the root environment rather than by the sulfur status of the plant itself.

Methionine is an essential metabolite in plants and all-living organisms (Ravanel et al. 1998). Apart from a role as a protein constituent, methionine is the precursor of $S$-adenosyl-L-methionine (SAM), the primary biological methyl-group donor (Roje 2006). The highly reactive methylated sulfur of SAM is used by a broad range of methyltransferases (Poel et al. 2013). A by-product of SAM-dependent transmethylation, $S$-adenosylhomocysteine $(\mathrm{SAH})$ is released, which is recycled to methionine via homocysteine through the activated methyl cycle (Bürstenbinder and Sauter 2012). SAH strongly inhibited methyltransferase through competition with the substrate SAM (Barbes et al. 1990; Moffatt and Weretilnyk 2001). The ratio of cellular SAH and SAM is indicative for the methylation capacity of the cell (Fulnecek et al. 2011; Poel et al. 2013). In the current study the impact of sulfate deprivation and $\mathrm{H}_{2} \mathrm{~S}$ exposure on the content of the metabolites involved in the active methyl cycle was studied in Chinese cabbage.

Seeds of Chinese cabbage (Brassica pekinensis (Lour.) Rupr. cv. Kasumi F1; Nickerson Zwaan, Made, The Netherlands) were germinated in vermiculite in a climate controlled room. Day and night temperatures were $22{ }^{\circ} \mathrm{C}$ and $18{ }^{\circ} \mathrm{C}$ $\left( \pm 1{ }^{\circ} \mathrm{C}\right)$, respectively, relative humidity of $60-70 \%$ and a $14-\mathrm{h}$ photoperiod at a photon fluence rate of $300 \pm 20 \mu \mathrm{mol} \mathrm{m} \mathrm{s}^{-2} \mathrm{~s}^{-1}(400-700 \mathrm{~nm})$ at plant height, supplied by Philips GreenPower LED (deep red/white 120) production modules. Ten-day-old seedlings were transferred to an aerated $25 \%$ Hoagland nutrient solution ( $\mathrm{pH} 5.9)$ with $0.5 \mathrm{mM}$ sulfate $(+\mathrm{S}$, sulfate sufficient) or $0 \mathrm{mM}$ sulfate $(-\mathrm{S}$, sulfate deprived; all sulfate salts replaced by chloride salts) in 131 stainless 
steel containers (ten sets of plants per container, three plants per set). Plants were exposed to $0.2 \mu \mathrm{l} \mathrm{l}^{-1} \mathrm{H}_{2} \mathrm{~S}$ in 1501 cylindrical stainless steel cabinets $(0.6 \mathrm{~m}$ diameter) with a poly(methylmethacrylate) top. The lids of the containers and the plant sets were sealed in order to prevent absorption of atmospheric $\mathrm{H}_{2} \mathrm{~S}$ by the nutrient solution. Day and night temperatures in the fumigation cabinets were 22 and $19{ }^{\circ} \mathrm{C}\left( \pm 2{ }^{\circ} \mathrm{C}\right)$, respectively, and relative humidity was $40-50 \%$. The photoperiod was $14 \mathrm{~h}$ at a photon fluence rate of $300 \pm 20 \mu \mathrm{mol} \mathrm{m} \mathrm{m}^{-2} \mathrm{~s}^{-1}$ (within the 400-700 nm range) at plant height, supplied by Philips GreenPower LED (deep red/white 120) production modules. The air exchange was $401 \mathrm{~min}^{-1}$, whereas a ventilator stirred the air inside the cabinets continuously. Pressurized $\mathrm{H}_{2} \mathrm{~S}$ diluted with $\mathrm{N}_{2}\left(1 \mathrm{ml} \mathrm{l}^{-1}\right)$ was injected into the incoming air stream and the concentration in the cabinet was adjusted to the desired level using electronic mass flow controllers (ASM, Bilthoven, The Netherlands). The air exchange was $401 \mathrm{~min}^{-1}$, and a ventilator stirred the air inside the cabinets continuously. The $\mathrm{H}_{2} \mathrm{~S}$ concentration in the cabinets was monitored by an $\mathrm{SO}_{2}$ analyzer (model 9850) equipped with a $\mathrm{H}_{2} \mathrm{~S}$ converter (model 8770; Monitor Labs, Measurement Controls Corporation, Englewood, CO, USA). Plants were harvested after $\mathrm{H}_{2} \mathrm{~S}$ exposure. Roots were separated from shoots, weighed, and were frozen immediately in liquid $\mathrm{N}_{2}$ and stored at $-80{ }^{\circ} \mathrm{C}$ until further use. For determination of the sulfur metabolites, plant tissue was freeze-dried at $-60{ }^{\circ} \mathrm{C}$ for $48-72 \mathrm{~h}$. Freeze-dried plant tissues were ground to powder with liquid nitrogen in a mortar with pestle. The sulfur metabolites were extracted as described in (Chang et al. 2013). For isotope dilution mass spectrometry analysis, the ${ }^{34} \mathrm{~S}$-labeled Arabidopsis thaliana tissue were extracted and added to the calibration standards, QC samples, and plant samples in a fixed ratio (Chang et al. 2013). Chromatographic separations of sulfur metabolites were performed on a Thermo Accela LC system using a Thermo Scientific Hypersil Gold aQ C18 $(1.9 \mu \mathrm{m}, 2.1 \mathrm{~mm} \times 10 \mathrm{~cm})$. Separations were performed under isocratic condition at a flow rate of $0.25 \mathrm{ml} \mathrm{min}^{-1}$. The mobile phase was composed of $0.1 \%$ formic acid in water. ESI-MS/MS analysis was performed on a Thermo Scientific TSQ Quantum Ultra. Metabolites were detected in positive ionization mode using multiple reaction monitoring scanning mode. The spray voltage was set to $3.5 \mathrm{kV}$, the ion-transfer capillary temperature was set to $280{ }^{\circ} \mathrm{C}$, the sheath gas pressure was set to 50 (arbitrary units), and the auxiliary gas pressure was set to 15 (arbitrary units). Collision energy set at $35 \%$ was used for each metabolite (Table 1).

An 11-day exposure of Chinese cabbage to sulfate-deprived condition resulted in a decreased plant biomass production (Table 2). The shoot growth was relatively more affected than the root growth resulting in a decrease in shoot/root ratio. Exposure of sulfate-sufficient plants to $0.2 \mu \mathrm{l}^{-1} \mathrm{H}_{2} \mathrm{~S}$ hardly affected plant biomass production, but it alleviated the reduction in biomass production of sulfate-deprived plants. The latter demonstrated that similar to previous observations that at an atmospheric $\mathrm{H}_{2} \mathrm{~S}$ concentration $\geq 0.2 \mu \mathrm{l}^{-1}$ the foliarly absorbed sulfide fully could replace sulfate taken up by the sulfur source for growth (Koralewska et al. 2008; Shahbaz et al. 2014; Aghajanzadeh et al. 2014, 2016). $\mathrm{H}_{2} \mathrm{~S}$ exposure of sulfate-sufficient plants resulted in a slight increase in the total glutathione (expressed as GSH) content of the shoot and not of the root (Table 3). Sulfate 
Table 1 Mass spectrometry parameters with transition pairs in MRM mode and normalized collision energy (\%)

\begin{tabular}{l|l|l|l}
\hline Compound name & Precursorion & Production & Collision energy \\
\hline Methionine & 150 & 56 & 15 \\
\hline Methionine S34 & 152 & 106 & 15 \\
\hline GSH & 308 & 162 & 20 \\
\hline GSH S34 & 310 & 181 & 20 \\
\hline SAH & 385 & 134 & 20 \\
\hline SAH S34 & 387 & 136 & 20 \\
\hline SAM & 399 & 250 & 20 \\
\hline SAM S34 & 401 & 250 & 20 \\
${ }^{32}$ S GSSG & 613 & 355 & 25 \\
\hline${ }^{34}$ S GSSG & 617 & 359 & 25 \\
\hline
\end{tabular}

Table 2 Impact of $\mathrm{H}_{2} \mathrm{~S}$ and sulfate deprivation on biomass production of shoots and roots of Chinese cabbage

\begin{tabular}{l|l|l|l|l}
\hline & + Sulfate & \multicolumn{4}{l}{-Sulfate } & \\
\cline { 2 - 5 } & $0 \mu 1^{-1} \mathrm{H}_{2} \mathrm{~S}$ & $0.2 \mu 1^{-1} \mathrm{H}_{2} \mathrm{~S}$ & $0 \mu 11^{-1} \mathrm{H}_{2} \mathrm{~S}$ & $0.2 \mu 11^{-1} \mathrm{H}_{2} \mathrm{~S}$ \\
\hline Shoot $(\mathrm{g} \mathrm{FW})$ & $3.98 \pm 0.38 \mathrm{~b}$ & $5.39 \pm 1.91 \mathrm{~b}$ & $1.12 \pm 0.04 \mathrm{a}$ & $4.69 \pm 0.66 \mathrm{~b}$ \\
\hline Root $(\mathrm{g} \mathrm{FW})$ & $0.78 \pm 0.05 \mathrm{~b}$ & $1.05 \pm 0.26 \mathrm{~b}$ & $0.33 \pm 0.04 \mathrm{a}$ & $1.10 \pm 0.08 \mathrm{c}$ \\
\hline Shoot/root ratio & $5.13 \pm 0.27 \mathrm{~b}$ & $5.29 \pm 1.75 \mathrm{ba}$ & $3.46 \pm 0.44 \mathrm{a}$ & $4.27 \pm 0.27 \mathrm{a}$ \\
\hline
\end{tabular}

Ten-day-old seedlings were grown on a $25 \%$ Hoagland solution at 0 and $0.5 \mathrm{mM}$ sulfate $(+\mathrm{S})$ and exposed to $0.2 \mu 11^{-1} \mathrm{H}_{2} \mathrm{~S}$ for 11 days. The initial fresh biomass of the shoot and root of Chinese cabbage was $0.171 \pm 0.001 \mathrm{~g}$ and $0.057 \pm 0.001 \mathrm{~g}$, respectively. Data on plant yield (g FW) and shoot/root ratio represent the mean of three measurements with three plants in each $( \pm \mathrm{SD})$ Means with different letters are significant different at $\mathrm{p}<0.01$ (unpaired Student's t-test)

deprivation resulted in a strong decrease in the glutathione content of both shoot and root but this decrease was largely alleviated upon $\mathrm{H}_{2} \mathrm{~S}$ exposure, though its content remained lower than that of the sulfate-sufficient plants. Sulfate deprivation also resulted in a substantial decrease in the methionine and SAH content of both shoot and root and SAM content of the root (Table 3). However, the SAM content of the shoot was hardly affected upon sulfate deprivation, resulting in a fourfold increase in the SAM/SAH ratio (Table 3). The SAM/SAH ratio in plant tissue has often been used as a reporter of the methylation capacity ("methylation index"; Groth et al. 2016). In this view the increase in SAM/SAH ratio in the shoot upon sulfate deprivation would indicate an increased methylation capacity. Exposure of sulfate-deprived plants to $\mathrm{H}_{2} \mathrm{~S}$ alleviated the decrease in SAM and SAH content of the shoots, which were comparable to that of shoots of sulfate-sufficient plants (Table 3). However, the methionine content was slightly lower than that of sulfatesufficient plants. The contents of methionine, SAM and SAH sulfur of the roots were decreased upon sulfate deprivation, whereas the content of these sulfur metabolites in the root of sulfate-deprived $\mathrm{H}_{2} \mathrm{~S}$-exposed plants was quite similar to that of sulfate-sufficient plants. The activated methyl cycle is a central metabolic 
Table 3 Impact of $\mathrm{H}_{2} \mathrm{~S}$ and sulfate deprivation on the content of glutathione and metabolites of activated methyl cycle in shoots and roots of Chinese cabbage

\begin{tabular}{|c|c|c|c|c|}
\hline & \multicolumn{2}{|l|}{ +Sulfate } & \multicolumn{2}{|l|}{-Sulfate } \\
\hline & $0 \mu \mathrm{ll}^{-1} \mathrm{H}_{2} \mathrm{~S}$ & $0.2 \mu \mathrm{l}^{-1} \mathrm{H}_{2} \mathrm{~S}$ & $0 \mu \mathrm{ll}^{-1} \mathrm{H}_{2} \mathrm{~S}$ & $0.2 \mu \mathrm{ll}^{-1} \mathrm{H}_{2} \mathrm{~S}$ \\
\hline \multicolumn{5}{|l|}{ Shoot } \\
\hline Glutathione & $5.67 \pm 0.22 \mathrm{c}$ & $6.69 \pm 0.42 \mathrm{~d}$ & $0.18 \pm 0.01 \mathrm{a}$ & $3.87 \pm 0.16 b$ \\
\hline Methionine & $0.224 \pm 0.004 c$ & $0.260 \pm 0.039 c$ & $0.038 \pm 0.006 \mathrm{a}$ & $0.179 \pm 0.032 b$ \\
\hline SAM & $0.123 \pm 0.008 \mathrm{ab}$ & $0.134 \pm 0.011 b$ & $0.106 \pm 0.011 \mathrm{a}$ & $0.113 \pm 0.007 \mathrm{a}$ \\
\hline SAH & $0.015 \pm 0.001 \mathrm{~b}$ & $0.014 \pm 0.001 \mathrm{~b}$ & $0.003 \pm 0.001 \mathrm{a}$ & $0.012 \pm 0.001 \mathrm{~b}$ \\
\hline SAM/SAH ratio & $8.2 \pm 1.1 \mathrm{a}$ & $9.6 \pm 1.5 \mathrm{a}$ & $35.3 \pm 15.4 b$ & $9.4 \pm 1.4 \mathrm{a}$ \\
\hline \multicolumn{5}{|l|}{ Root } \\
\hline Glutathione & $4.62 \pm 0.15 c$ & $5.17 \pm 0.54 c$ & $0.55 \pm 0.07 \mathrm{a}$ & $2.79 \pm 0.10 b$ \\
\hline Methionine & $0.136 \pm 0.014 b$ & $0.135 \pm 0.024 b$ & $0.024 \pm 0.004 a$ & $0.121 \pm 0.004 b$ \\
\hline SAM & $0.207 \pm 0.002 b$ & $0.210 \pm 0.024 b c$ & $0.076 \pm 0.016 \mathrm{a}$ & $0.231 \pm 0.002 \mathrm{c}$ \\
\hline SAH & $0.019 \pm 0.002 b c$ & $0.017 \pm 0.002 b$ & $0.006 \pm 0.003 \mathrm{a}$ & $0.021 \pm 0.002 \mathrm{c}$ \\
\hline SAM/SAH ratio & $10.9 \pm 1.3 \mathrm{a}$ & $12.3 \pm 2.9 \mathrm{a}$ & $12.3 \pm 8.6 \mathrm{a}$ & $11.0 \pm 1.1 \mathrm{a}$ \\
\hline
\end{tabular}

For experimental details, see legends of Table 2. Data on metabolite content is expressed as $\mu \mathrm{mol} g$

${ }^{-1}$ dry weight (freeze-dried plant material) and represent mean of three measurements with three plants in each $( \pm \mathrm{SD})$. Means with different letters are significant different at $\mathrm{p}<0.01$ (unpaired Student's t-test)

pathway responsible for the methylation of cellular components and the recycling of sulfur-containing metabolites. The methylation of essential biological molecules, e.g. nucleic acids, hormones, lipids, proteins, is of crucial importance for many key biochemical processes (Chiang et al. 1996). Apparently the foliarly absorbed sulfide by sulfate-deprived Chinese cabbage upon exposure to an atmospheric level of $0.2 \mu \mathrm{l} \mathrm{l}^{-1} \mathrm{H}_{2} \mathrm{~S}$ was sufficient for reduced sulfur requirement of the plant to support growth and to maintain the levels of the metabolites involved in the activated methyl cycle in both the shoot and the root.

Acknowledgements We would like to thank Dr. Ding-Tzai Li for all fruitful discussions and Mass Solution Technology Co., Ltd. for their excellent technical support.

\section{References}

Aghajanzadeh T, Hawkesford MJ, De Kok LJ (2014) The significance of glucosinolates for sulfur storage in Brassicaceae seedlings. Front Plant Sci 5:704

Aghajanzadeh T, Hawkesford MJ, De Kok LJ (2016) Atmospheric $\mathrm{H}_{2} \mathrm{~S}$ and $\mathrm{SO}_{2}$ as sulfur sources for Brassica juncea and Brassica rapa: regulation of sulfur uptake and assimilation. Environ Exp Bot 124:1-10

Barbes C, Sanchez J, Yebra MJ, Robert-Gero M, Hardisson C (1990) Effects of sinefungin and Sadenosylhomocysteine on DNA and protein methyltransferases from Streptomyces and other bacteria. FEMS Microbiol Lett 57:239-243 
Buchner P, Stuiver CEE, Westerman S, Wirtz M, Hell R, Hawkesford MJ, De Kok LJ (2004) Regulation of sulfate uptake and expression of sulfate transporter genes in Brassica oleracea as affected by atmospheric $\mathrm{H}_{2} \mathrm{~S}$ and pedospheric sulfate nutrition. Plant Physiol 136:3396-3408

Bürstenbinder K, Sauter M (2012) Early events in the ethylene biosynthetic pathway - regulation of the pools of methionine and Sadenosylmethionine. In: MT MM (ed) The plant hormone ethylene, Annual plant review, vol 44. Wiley, Oxford, pp 19-52

Chang YL, Hsieh CL, Huang YM, Chiou WL, Kuo YH, Tseng MH (2013) Modified method for determination of sulfur metabolites in plant tissues by stable isotope dilution-based liquid chromatography electrospray ionization tandem mass spectrometry. Anal Biochem 442:24-33

Chiang PK, Gordon RK, Tal J, Zeng GC, Doctor BP, Pardhasaradhi K, McCann PP (1996) SAdenosylmethionine and methylation. FASEB J 10:471-480

De Kok LJ (1990) Sulfur metabolism in plants exposed to atmospheric sulfur. In: Rennenberg H, Brunold C, De Kok LJ, Stulen I (eds) Sulfur nutrition and sulfur assimilation in higher plants: fundamental environmental and agricultural aspects. Backhuys Publishers, Leiden, pp $111-130$

De Kok LJ, Stuiver CEE, Westerman S, Stulen I (2000) Atmospheric $\mathrm{H}_{2} \mathrm{~S}$ as plant sulfur source: interaction with pedospheric sulfur nutrition - a case study with Brassica oleracea L. In: Brunold C, Rennenberg H, De Kok LJ, Stulen I, Schnug E, Davidian J-C (eds) Sulfur nutrition and sulfur assimilation in higher plants: molecular biochemical and physiological aspects. Verlag Paul Haupt, Bern, pp 41-55

De Kok LJ, Stuiver CEE, Westerman S, Stulen I (2002) Elevated levels of hydrogen sulfide in the plant environment: nutrient or toxin. In: Omasa K, Saji H, Youssefian S, Kondo N (eds) Air pollution and plant biotechnology. Prospects for phytomonitoring and phytoremediation. Springer, Tokyo, pp 3-11

De Kok LJ, Durenkamp M, Yang L, Stulen I (2007) Atmospheric sulfur. In: Hawkesford MJ, De Kok LJ (eds) Sulfur in plants: an ecological perspective. Springer, Dordrecht, pp 91-106

Fulnecek J, Matyasek R, Votruba I, Holy A, Krizova K, Kovarik A (2011) Inhibition of SAH-hydrolase activity during seed germination leads to deregulation of flowering genes and altered flower morphology in tobacco. Mol Gen Genomics 285:225-236

Groth M, Moissiard G, Wirtz M, Wang H, Garcia-Salinas C, Ramos-Parra PA, Smith DC, Zhai J, Hale CJ, Long JA, Hell R, Díaz de la Garza RI, Jacobsen SE (2016) MTHFD1 controls DNA methylation in Arabidopsis. Nat Commun 7:1-13

Koralewska A, Posthumus FS, CEE S, Buchner P, De Kok LJ (2007) The characteristic high sulfate content in Brassica oleracea is controlled by the expression and activity of sulfate transporters. Plant Biol 9:654-661

Koralewska A, Stuiver CEE, Posthumus FS, Kopriva S, Hawkesford MJ, De Kok LJ (2008) Regulation of sulfate uptake expression of the sulfate transporters Sultr1;1 and Sultr1;2, and APS reductase in Chinese cabbage (Brassica pekinensis) as affected by atmospheric $\mathrm{H}_{2} \mathrm{~S}$ nutrition and sulfate deprivation. Funct Plant Biol 35:318-327

Koralewska A, Posthumus FS, Stuiver CEE, Shahbaz M, Stulen I, De Kok LJ (2012) Regulation of the uptake of sulfate by Chinese cabbage (Brassica pekinensis) at various sulfate concentrations. In: De Kok LJ, Tausz M, Hawkesford MJ, Hoefgen R, McManus MT, Norton RM, Rennenberg H, Saito K, Schnug E, Tabe L (eds) Sulfur metabolism in plants - mechanisms and applications to food security and responses to climate change. Springer, Dordrecht/New York, pp 61-65

Moffatt BA, Weretilnyk EA (2001) Sustaining S-adenosyl-L-methionine-dependent methyltransferase activity in plant cells. Physiol Plant 113:435-442

Poel BV, Bulens I, Oppermann Y, Hertog MLA, Nicolai BM, Sauter M, Gerard AH (2013) $S$-Adenosyl-L-methionine usage during climacteric ripening of tomato in relation to ethylene and polyamine biosynthesis and transmethylation capacity. Physiol Plant 148:176-188

Ravanel S, Gakiere B, Job D, Douce R (1998) The specific features of methionine biosynthesis and metabolism in plants. Proc Natl Acad Sci U S A 95:7805-7812

Roje S (2006) S-Adenosyl-L-methionine: beyond the universal methyl group donor. Phytochemistry 67:1686-1698 
Shahbaz M, Tseng M-H, Stuiver CEE, Koralewska A, Posthumus FS, Venema JH, Parmar S, Schat H, Hawkesford MJ, De Kok LJ (2010) Copper exposure interferes with the regulation of the uptake, distribution and metabolism of sulfate in Chinese cabbage. J Plant Physiol $167: 438-446$

Shahbaz M, Stuiver CEE, Posthumus FS, Parmar S, Hawkesford MJ, De Kok LJ (2014) Copper toxicity in Chinese cabbage is not influenced by plant sulphur status but affects sulphur metabolism-related gene expression and the suggested regulatory metabolites. Plant Biol 16:68-78

Stuiver CEE, Posthumus FS, Parmar S, Shahbaz M, Hawkesford MJ, De Kok LJ (2014) Zinc exposure has differential effects on uptake and metabolism of sulfur and nitrogen in Chinese cabbage. J Plant Nutr Soil Sci 177:748-757 